INDEPENDENT JOURNAL OF MANAGEMENT \& PRODUCTION (IJM\&P)

DOI: 10.14807/ijmp.v9i5.810

\title{
DISCRETE SIMULATION APPLIED TO A GAS APPLIANCE COMPANY
}

Márcio Rodrigues Clementino Instituto Federal de São Paulo - Campus Suzano E-mail: clementino_marcio@hotmail.com

Thais Taba da Silva Instituto Federal de São Paulo - Campus Suzano

E-mail: thaistaba.s@gmail.com

Adriano Maniçoba da Silva Instituto Federal de São Paulo - Campus Suzano

E-mail: adrianoms@ifsp.edu.br

Wilson Yoshio Tanaka Instituto Federal de São Paulo - Campus Suzano E-mail: w.tanaka@ifsp.edu.br

Eugenio de Felice Zampini Instituto Federal de São Paulo - Campus Suzano

E-mail: eugenio.zampini@ifsp.edu.br

Submission: $29 / 03 / 2018$

Accept: 29/03/2018

\section{ABSTRACT}

The proper management of the operations is fundamental to the companies' results, and, particularly, the continuous improvement in production processes is extremely important to raise the level of efficiency. The present study aimed to simulate the process of welding of a component called heat exchanger that makes up a gas water heater. Then, this simulation has the objective of optimizing the production process. The data collected were obtained from a company located in Mogi das Cruzes, São Paulo. The results of the simulation model point to opportunities for improvement, mainly in the direction of reducing work shifts.

Keywords: Discrete simulation, welding process, productive efficiency 
DOI: 10.14807/ijmp.v9i5.810

\section{INTRODUCTION}

The market is in an accelerated process of change, whose intensity increases as new ideas for technological and logistical improvement emerge. This fact can be clearly seen in recent years. As the market's demand for quality, price and customization grows, systems are challenged, being required continual improvements to exceed their own limits in order to achieve better performance levels with a view to ensuring that they remain in the market.

In this scenario, there is a continuous need to obtain advantages that distinguish a company from its competitors in order to achieve a prominent position in the market. Through operational research it is possible to develop innovative technologies to obtain a competitive advantage and thus gain market leadership.

The use of operational research and simulation can improve the production line processes, particularly in the segment object of this paper that is a gas water heater factory, using the study of times and methods. The process simulation technique is useful for analyzing the behavior of queues and the relationship between several components of a system, considering the flow of information and physical elements.

The study in this segment is justified because, in the analysis undertaken in the company, the heat exchanger is the piece that represents greater value in the heater assembly; then, the focus in the continuous improvement in its productive process is mandatory, due to the profit margin and in light of the current market with the expansion of competition in the sector and imports from Asia.

In this way, the present study aimed to simulate the process of welding a component called a heat exchanger that makes up a gas water heater with the purpose of optimizing the production process. From the simulation performed, improvement scenarios were created in order to obtain greater productive efficiency in the work cell and consequent elimination of existing bottlenecks.

\section{LITERATURE REVIEW}

\subsection{Production capacity and row organization}

According to Slack (2002), the operation of processes in an organization represents the collection of resources destined to the production of its goods and 
INDEPENDENT JOURNAL OF MANAGEMENT \& PRODUCTION (IJM\&P)

http://www.ijmp.jor.br

v. 9, n. 5, Special Edition IFLOG 2017

ISSN: 2236-269X

DOI: 10.14807/ijmp.v9i5.810

services. These resources form a set of activities and tasks, with the objective of unifying them becoming the final product that will be produced by the company for commercialization.

"For a good production planning, it is not enough to make the materials available at the right moment of its use, it must consider the existence of sufficient capacity to carry out this production" (CALIXTO, 2011). Therefore, the production is delimited to the factors of use of the product and its production capacity in the system, thus having a productive flow.

The production capacity is the maximum output that a factory can deliver. Martins (2005) states that capacity can be defined as the maximum level that can be achieved from value-added work considering normal operating conditions for a certain period of time.

According to Slack (2002) "The inefficient use of time will be transformed into extra operating cost" and, following the logic of this statement, the author makes an analogy of the cost of time with other fixed costs of a company, for example, factory rent or lighting costs, which tend to remain the same, or similar, over time, even the company producing large volumes of its goods, or even if it cannot produce the minimum needed to cover these fixed costs.

Conforming to Cox and Spencer (2002), "the strength of a single resource limits the output of the system, preventing performance improvement as a whole." Therefore, identifying exactly the limiting resource of the system output allows the company to achieve an increase in overall production performance without the need for a high level of investments.

In consonance with De Freitas Filho (2008), queuing theory is practically applied to any process or system that involves, in some way, the possibility of queuing due to constraints in the supply of resources in relation to demand. Once you have a resource to use, you may experience congestion if the resource is limited to the service.

In agreement with Andrade (2009), queuing theory deals with system congestion problems, whose main characteristic is the presence of clients requesting services that are not immediately available, so they should wait for their availability. 
Moreira (2010) considers that people associate the presence of queues with an excess of demand of a specific service over the capacity. However, it should be taken into account that the variability and dynamics of events also contribute to the formation of queues. Queues are formed not only by the lack of service capacity, but also due to the variability of the lead times, both in the time between arrivals and in the time of attendance of these objects.

\subsection{Chrono analysis}

According to Moreira (2004), it is possible to obtain the times of an operation in, at least, four different ways, they are:

1st. Time study with stopwatch;

2nd. Measurement of historical times;

3rd. Predetermined default data;

4th. Sample of work.

Moreira (2004) explains that the tolerance $(T)$ to be applied in the calculation to obtain the standard time has values that are foreseen in the table of typical values for the tolerance, and for the use of the values of this table to determine the tolerance $(T)$, all the conditions involved in the operation must be observed, adding the percentages identified in the table to the percentage of the time previously computed, that is, $100 \%$.

In other words, it can be said that when the normal time is obtained, this time will be considered the original value (100\%) for the calculation basis, and the tolerance factors (FT) obtained in the typical values table, when added to the obviously, will always result in a value greater than $100 \%$, the final value should be higher than normal time, this is precisely to be able to observe the effects of the operating conditions of the process studied.

After understanding how to find the standard time, we observe how the equation will look to determine the final values to be used in the simulation.

First, symbols are used that will be used to identify each type of time as follows:

$\mathrm{RT}=$ real time; 
$\mathrm{TN}=$ normal time;

$\mathrm{TP}=$ standard time;

Thus, to determine what the normal time will be:

$\mathrm{TN}=\mathrm{TR} \times \mathrm{EF} / 100$

Where EF = operator efficiency (\%).

At this point, called operator efficiency (EF), some value must be assigned in percentage to the analyzed operator, and $100 \%$ will be taken as the base if the analyst evaluates that the operator is inefficient, a certain percentage assumed by the analyst should be subtracted of $100 \%$. On the other hand, if the analyst evaluates an operator as above average, it should add up to $100 \%$ the assumed percentage. Thus, to determine what the normal time will be:

Once the normal time is obtained, the standard time can be calculated, marking the table of typical values to define the tolerance percentages for the operation, according to the formula:

$\mathrm{TP}=\mathrm{TN} \times \mathrm{FT} / 100$

Where FT = tolerance factor (\%), and we also have:

$\mathrm{FT}=100+\mathrm{T}$

Where $\mathrm{T}=$ tolerance (\%) allowed for the operation according to the typical values table.

\subsection{Simulation}

Currently, the process of simulation is used and accepted more frequently, due to the increasing computerized power in the workstations, associated with the improvement of environments for the development of computational friendly models (FREITAS FILHO, 2008).

When studying and planning one or more processes, problems arise such as the capacity dimensioning or the flow of processes that, several times, can have a complex solution. However, according to Andrade (2009), the experience gained in constructing the models and performing the simulation can lead to a better understanding of the system, which makes it possible to improve it. By means of 
INDEPENDENT JOURNAL OF MANAGEMENT \& PRODUCTION (IJM\&P)

http://www.ijmp.jor.br

v. 9, n. 5, Special Edition IFLOG 2017

ISSN: 2236-269X

DOI: 10.14807/ijmp.v9i5.810

several forms of model creation and the possibility of performing tests, it is possible to obtain the solution.

Chwif and Medina (2013), for the simulation study to be effective, proceed as follows:

1. Design or formulation of the model: make a clear modeling of the system to be simulated and the proposed objectives; obtaining input data through collection; creation of the conceptual model;

2. Conversion of the model: converter the conceptual model for the computational model; compare between the computational and conceptual model with objective of evaluation if the operation meets what was stipulated in the formulation of the initial model;

3. Analysis of the results of the model: apply several simulations of the model; analysis and documentation of results.

\section{METHODOLOGY}

In order to achieve the objective, a case study was conducted with a gas appliance company located in the city of Mogi das Cruzes in São Paulo. There is a production line in the company where the assembly of the gas water heater takes place. The cell where the welding process of the part called the heat exchanger is carried out serves to supply this production line that currently operates in two shifts for six days per week. Depending on the sales, the two shifts with the same number of employees working are able to supply the demand of the production line.

However, the heat exchanger welding cell has limited production, and routinely the production line needs more welded parts than its productive capacity, so there is an imbalance and the employees work overtime to supply the demand. Another measure adopted when this type of imbalance occurs is the provisional transfer of operators made by the production manager, where a welder of another process is relocated to supply the productive demand of the heat exchanger welding process, which is the main part of the heater assembly line.

This transfer generates an inconvenience for two productive sectors of the company, once the welding operator takes a shift to supply the demand of the gas water heater production line in another area; it fails to comply with the productive 
plan of its original sector. This leads to delays in production and deliveries, and generates some extra hours that tend to be eliminated with the completion of this simulation project. Then, the simulation undertaken allowed suggesting improvements to mitigate these adverse effects. The results are presented in the next section.

The simulation undertaken allowed to suggest improvements to mitigate these adverse effects. The results are presented in the next section.

\section{ANALYSIS OF RESULTS}

In order to create the model, it was necessary to analyze the steps of the cell to be studied, and the following steps were identified: Arrival, Welding Time, Cooling Time, Test Time, Water Tank Time, and thereafter collecting data from the times of each step of the welding cell of the heat exchanger in a sample period. 100 samples of the times in seconds presented in Tables 1 to 4 were used as the basis.

Table 1: Welding Time (in seconds)

\begin{tabular}{|r|r|r|r|r|r|r|r|r|r|}
\hline 120 & 115 & 122 & 117 & 110 & 111 & 112 & 123 & 110 & 100 \\
\hline 105 & 108 & 109 & 109 & 110 & 100 & 99 & 107 & 115 & 117 \\
\hline 119 & 113 & 114 & 112 & 119 & 120 & 125 & 100 & 116 & 110 \\
\hline 100 & 150 & 113 & 110 & 100 & 116 & 118 & 118 & 119 & 114 \\
\hline 112 & 113 & 114 & 118 & 115 & 98 & 99 & 118 & 114 & 122 \\
\hline 122 & 130 & 100 & 119 & 120 & 120 & 125 & 116 & 119 & 114 \\
\hline 120 & 129 & 111 & 111 & 124 & 129 & 116 & 118 & 120 & 129 \\
\hline 125 & 116 & 111 & 129 & 129 & 120 & 100 & 110 & 100 & 99 \\
\hline 97 & 116 & 117 & 117 & 119 & 122 & 122 & 120 & 116 & 128 \\
\hline 101 & 176 & 101 & 109 & 103 & 111 & 121 & 114 & 120 & 100 \\
\hline
\end{tabular}

Source: the authors, 2017

Table 2: Cooling Time (in seconds).

\begin{tabular}{|c|c|c|c|c|c|c|c|c|c|}
\hline 60 & 64 & 53 & 59 & 65 & 55 & 59 & 55 & 67 & 52 \\
\hline 59 & 55 & $\theta$ & 50 & 60 & 58 & 63 & 60 & 63 & 56 \\
\hline 58 & 50 & 6 & 55 & 70 & 59 & 50 & 52 & 50 & 59 \\
\hline 58 & 50 & ي & 60 & 50 & 63 & 58 & 54 & 59 & 58 \\
\hline 59 & 70 & 56 & 53 & 53 & 55 & 53 & 50 & 58 & 60 \\
\hline 65 & 60 & 60 & 65 & $6 i$ & 60 & 50 & 54 & 50 & 57 \\
\hline 57 & 55 & 55 & 57 & 55 & 58 & 57 & 52 & 55 & 64 \\
\hline 54 & 58 & 55 & 54 & 57 & 58 & 50 & 70 & 52 & 80 \\
\hline 63 & 58 & 53 & 55 & 56 & 57 & 59 & 47 & 59 & 62 \\
\hline 65 & 58 & 60 & 69 & 58 & 50 & 65 & 55 & 60 & 52 \\
\hline
\end{tabular}

Source: the authors, 2017 
INDEPENDENT JOURNAL OF MANAGEMENT \& PRODUCTION (IJM\&P)

http://www.ijmp.jor.br

v. 9, n. 5, Special Edition IFLOG 2017

ISSN: 2236-269X

DOI: 10.14807/ijmp.v9i5.810

Table 3: Test Time (in seconds).

\begin{tabular}{|l|l|l|l|l|r|r|r|r|r|}
\hline 80 & 83 & 82 & 84 & 84 & 86 & 85 & 88 & 89 & 90 \\
\hline 85 & 83 & 81 & 80 & 90 & 87 & 86 & 84 & 81 & 80 \\
\hline 84 & 90 & 91 & 86 & 85 & 88 & 87 & 83 & 82 & 82 \\
\hline 81 & 88 & 83 & 82 & 81 & 89 & 96 & 80 & 80 & 80 \\
\hline 83 & 82 & 81 & 84 & 83 & 82 & 83 & 84 & 88 & 89 \\
\hline 84 & 84 & 83 & 83 & 83 & 81 & 82 & 82 & 82 & 80 \\
\hline 83 & 85 & 86 & 87 & 99 & 85 & 83 & 82 & 84 & 85 \\
\hline 85 & 81 & 82 & 80 & 88 & 86 & 83 & 83 & 90 & 82 \\
\hline 84 & 83 & 83 & 83 & 84 & 83 & 82 & 83 & 83 & 82 \\
\hline 81 & 80 & 80 & 83 & 85 & 86 & 87 & 80 & 81 & 82 \\
\hline
\end{tabular}

Table 4: Tank Test Time (in seconds).

\begin{tabular}{|l|l|l|l|l|r|r|r|r|r|}
\hline 50 & 40 & 45 & 50 & 47 & 48 & 55 & 52 & 50 & 50 \\
\hline 50 & 60 & 60 & 45 & 40 & 60 & 50 & 50 & 60 & 60 \\
\hline 35 & 80 & 45 & 46 & 49 & 41 & 42 & 48 & 47 & 50 \\
\hline 50 & 58 & 60 & 80 & 55 & 57 & 55 & 42 & 48 & 40 \\
\hline 50 & 66 & 55 & 58 & 50 & 50 & 50 & 45 & 45 & 45 \\
\hline 47 & 45 & 47 & 49 & 41 & 42 & 43 & 46 & 46 & 55 \\
\hline 60 & 60 & 90 & 90 & 50 & 40 & 40 & 40 & 50 & 45 \\
\hline 46 & 49 & 47 & 48 & 48 & 42 & 52 & 41 & 52 & 52 \\
\hline 53 & 57 & 50 & 50 & 50 & 50 & 40 & 42 & 46 & 45 \\
\hline 41 & 40 & 41 & 42 & 41 & 41 & 41 & 42 & 49 & 49 \\
\hline
\end{tabular}

It was also verified the form of probability distribution associated to the times collected. The histograms of the data are shown in Figure 1. 


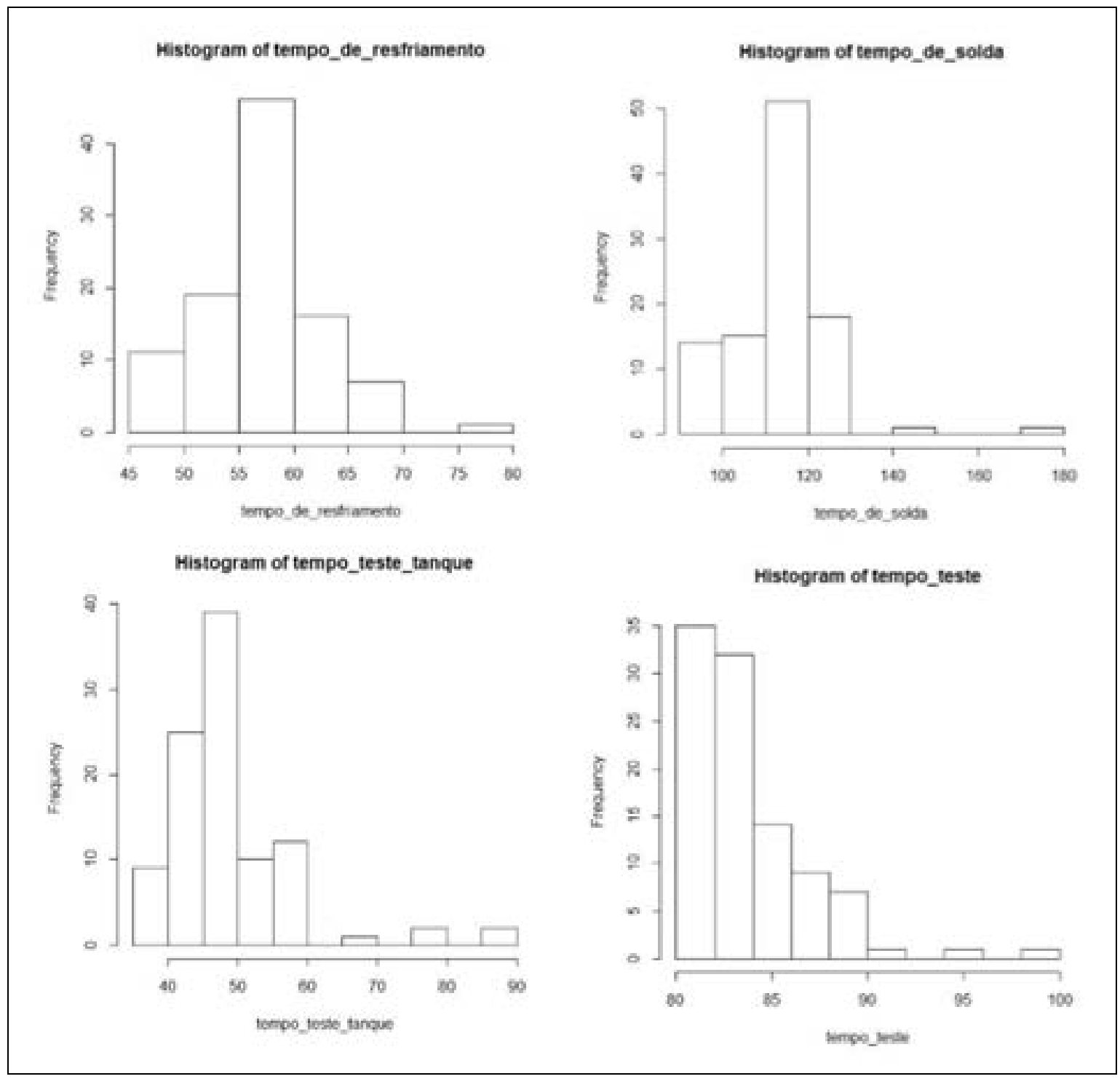

Figure 1: Histograms of collected data Source Source: the authors, 2017

With the data obtained, an adhesion test was performed with the Input Analyzer tool of the Arena simulator, to find the best distribution in the behavior of this queue. The results of the analysis are shown in Table 5.

Table 5: Results of the adhesion test.

\begin{tabular}{|c|c|c|c|c|}
\hline Data & $\begin{array}{l}\text { Probability } \\
\text { distribution }\end{array}$ & Parameters & Quadratic error & $\begin{array}{c}\text { Significance of the } \\
\text { Chi-Square Test }\end{array}$ \\
\hline Welding time & Normal & $\begin{array}{c}\text { Average } 115 \text { and } \\
\text { standard deviation } 10,9\end{array}$ & 0,019 & $<0,005$ \\
\hline Cooling time & Normal & $\begin{array}{c}\text { Average } 58,4 \text { and } \\
\text { standard deviation } 5,49\end{array}$ & 0,021 & 0,0824 \\
\hline Test time in tank & Gamma & $\begin{array}{l}34,5 \text { added to Beta of } \\
4,91 \text { and Alpha of } 3,11\end{array}$ & 0,042 & $<0,005$ \\
\hline Test time & Weibull & $\begin{array}{c}79,5 \text { added Beta of } \\
4,98 \text { and Alpha of } 1,41\end{array}$ & 0,010 & 0,133 \\
\hline
\end{tabular}


As can be seen in Table 5, the non-significant distributions, that is, those that did not differ from the indicated distributions were the cooling time and that of the test time. In this way, the simulation will be conducted with the limitation that the welding time and the test time of the tank will be simulated with the indicated distributions even though they have not been validated in the adhesion test.

For the part entry, a series of timekeeping was performed, where an average interval of 6,233 seconds between line supply arrivals was observed, and from the calculation below, a standard time of 7,200 seconds was obtained considering a total efficiency (EF) of $105 \%$, and the final result of this calculation to obtain the standard arrival time was used in the Arena to simulate the operation.

Figuring out the standard time of arrival:

$\mathrm{TN}=\mathrm{TR} \times \mathrm{EF} / 100$

$\mathrm{TN}=6,233 \times 105 / 100=6,545$

The following tolerance values were considered to be applied to the normal time according to the typical values table:

1st Personal time - 5\%;

2nd Basic fatigue - 4\%;

$3^{\circ}$ Average Monotony - 1\% .v

A total of $10 \%$ of tolerance factor (FT) obtained should be added as follows:

$\mathrm{FT}=100+\mathrm{T}$

$\mathrm{FT}=100+10=110 \%$

Finally, you will find the default time from the calculation below:

$\mathrm{TP}=\mathrm{TN} \times \mathrm{FT} / 100$

$\mathrm{TP}=6,545 \times 110 / 100=7,200$

For the output of pieces, a series of timekeeping was carried out, in which an average of 109 seconds was observed to perform the movement of the cart loaded with finished pieces to the production line, and from the calculation a standard time of 120 seconds was obtained considering a (EF) of $100 \%$, and the final result of this 
INDEPENDENT JOURNAL OF MANAGEMENT \& PRODUCTION (IJM\&P)

http://www.ijmp.jor.br

v. 9, n. 5, Special Edition IFLOG 2017

ISSN: 2236-269X

DOI: 10.14807/ijmp.v9i5.810

calculation to obtain the standard exit time was used in the Arena to simulate the operation.

For this calculation there is no increase by efficiency factor (EF), since in this operation efficiency was considered within the average, that is, $100 \%$ of total efficiency. In addition, the same tolerance values used for the calculation of the standard time of arrival are considered, so there is a total increase of $10 \%$ per tolerance factor (FT). However, even though these values are the same, there is a substitution of the average monotony factor for the factor of use of muscular strength in 10 pounds, which according to the table of typical values is maintained with the same percentage of $1 \%$ to apply to the calculation. After making the necessary considerations, the calculations to obtain the standard exit time will be:

Calculation of the standard output time:

$$
\begin{aligned}
& \mathrm{FT}=100+\mathrm{T} \\
& \mathrm{FT}=100+10=110 \% \\
& \mathrm{TP}=\mathrm{TN} \times \mathrm{FT} / 100 \\
& \mathrm{TP}=109 \times 110 / 100=120
\end{aligned}
$$

\subsection{Simulation model}

The simulation model is presented in Figure 2 after performing the adhesion test with the objective of modelling in the Arena the current scenario, with the actual times for the simulation to be performed.

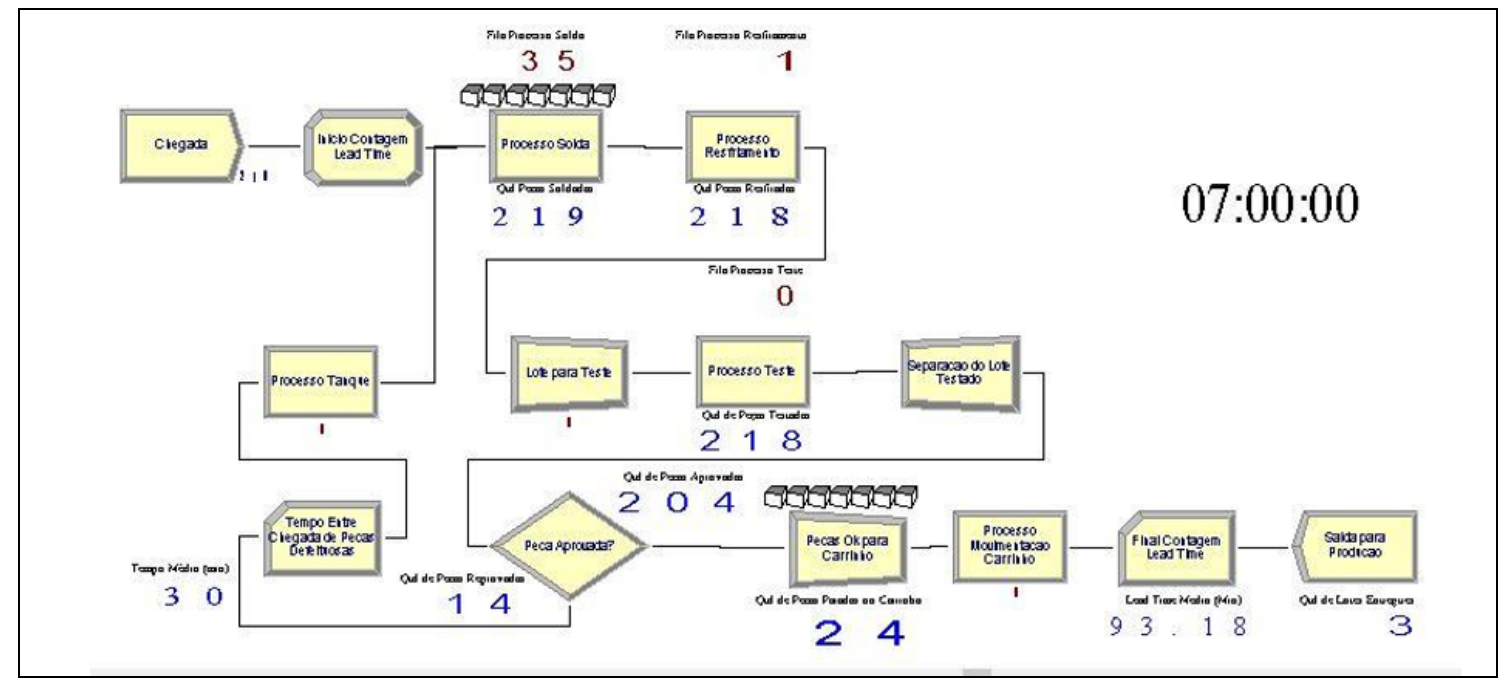

Figure 2: Current Cell Scenario

Source: The authors (2017 
The cell process begins with the arrival of parts that is estimated according to the production demand, in the standard time of 7,200 seconds. After the batch arrives, the exchangers are welded by the welder. Then, the part that was welded is cooled and after cooling the part goes to the test process.

If the piece is approved, it goes to the lot of pieces tested where it will form a single lot that will be moved to the production line by a cart whose default time is 120 seconds. In case of failure of the part, it goes to the sealing tank process. After the tightness test is performed on the tank, the helper identifies the weld failure on the part and returns it to the welder to rework the weld points.

After the model was simulated for 7 hours, the simulator generated a report with information presented in Figure 3.

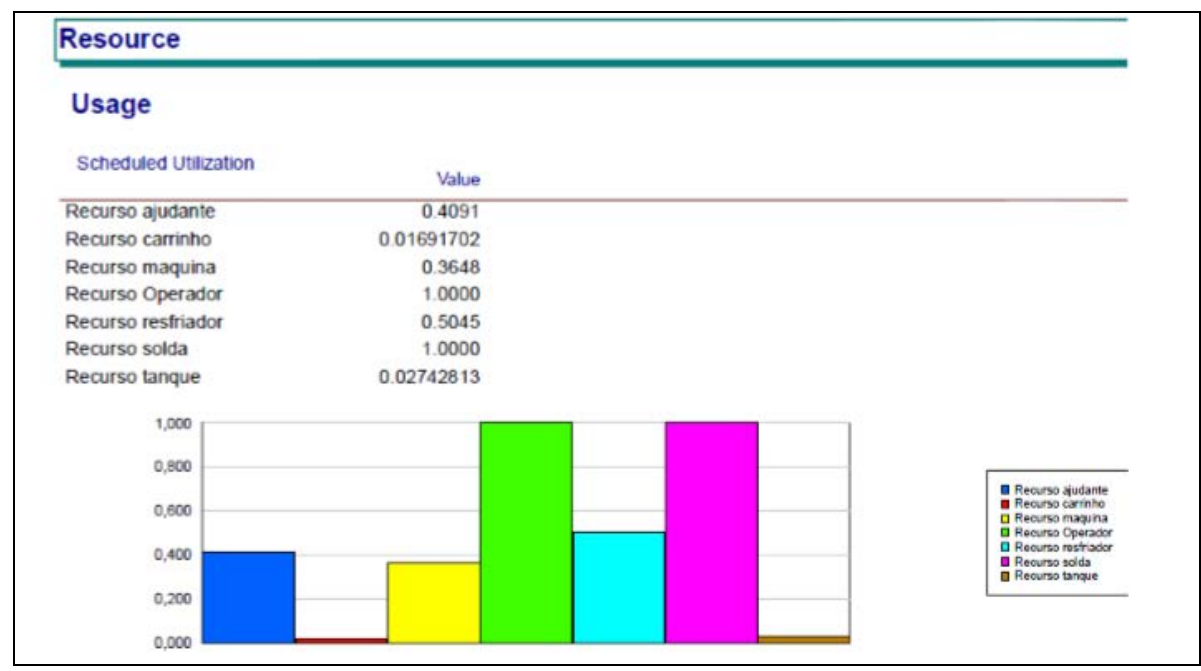

Figure 3: Graph of Utilization of Source

Source: The authors (2017

According to the data in Figure 3, which are presented in percentages, it is possible to verify that the idleness of the helper resource is at $59.09 \%$ of the working time, while the refuse operator using another Welding resource is in use for $100 \%$ of the working time shift. According to the data collected and treated with the Arena tool and its presented results, it is concluded that the operator resource and the solder resource are the bottlenecks of the system.

In this way, the presented scenario is explicitly unbalanced by the fact of idleness of a collaborator and in counterpart to the total use of another collaborator. 
DOI: 10.14807/ijmp.v9i5.810

\subsection{Improvement opportunities}

Considering the data presented in the previous analysis, one can identify the system two bottlenecks to be explored: the Welding process and the idleness of the helper who tests the exchangers.

\subsubsection{Welding process}

Currently the welding process has its capacity to use the resource in $100 \%$, which limits the system in its productive capacity, so it is necessary to analyze the reasons that lead to this occurrence. A hypothesis raised by the fact that the welding time is the process that demands more time within the lead time of the production cell.

\subsubsection{Helper}

According to the data collected and the process simulated by the Arena tool, it is noted that the level of productive efficiency of the auxiliary resource that assists the welding process is approximately $41 \%$, and the processes performed by it to assist the welding of the exchanger of heat has as a percentage of $36.48 \%$ for test machine, $50,45 \%$ for the heat exchanger solder chiller and $27.43 \%$ of the tank that performs the leakage test performed on the exchangers that are deprecated on the test machine. Therefore, the welding process of the heat exchanger is not limited by the performance of the helper assisting the process, since it is capable of performing all the auxiliary activities of the welding process and yet it is very idle in the 7-hour shift.

\subsubsection{Proposed scenario}

After the modeling and simulation with the actual times of the work cell, the proposal is a new scenario where improvements are applied to this work cell, with the objective of balancing the level of resource utilization and thus eliminating one of the bottlenecks (Figures 4 and 5). 
ISSN: 2236-269X

DOI: 10.14807/ijmp.v9i5.810

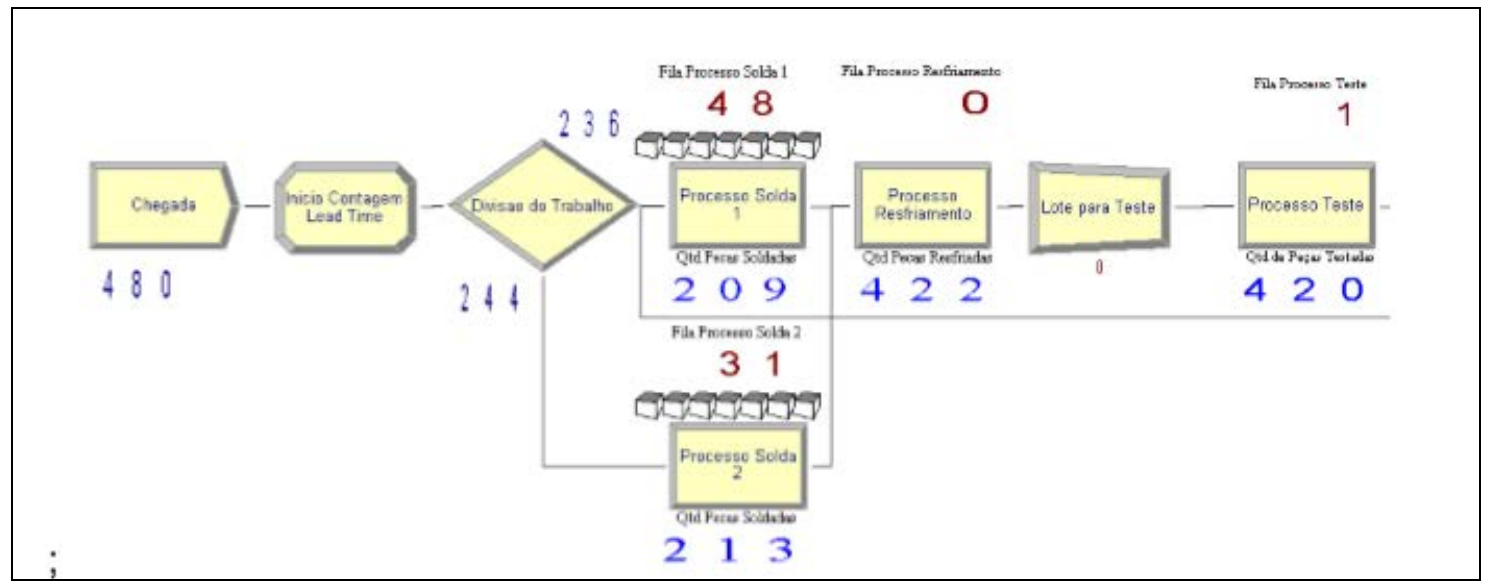

Figure 4: New proposed scenario (Part 1)

Source: Authors (2017)

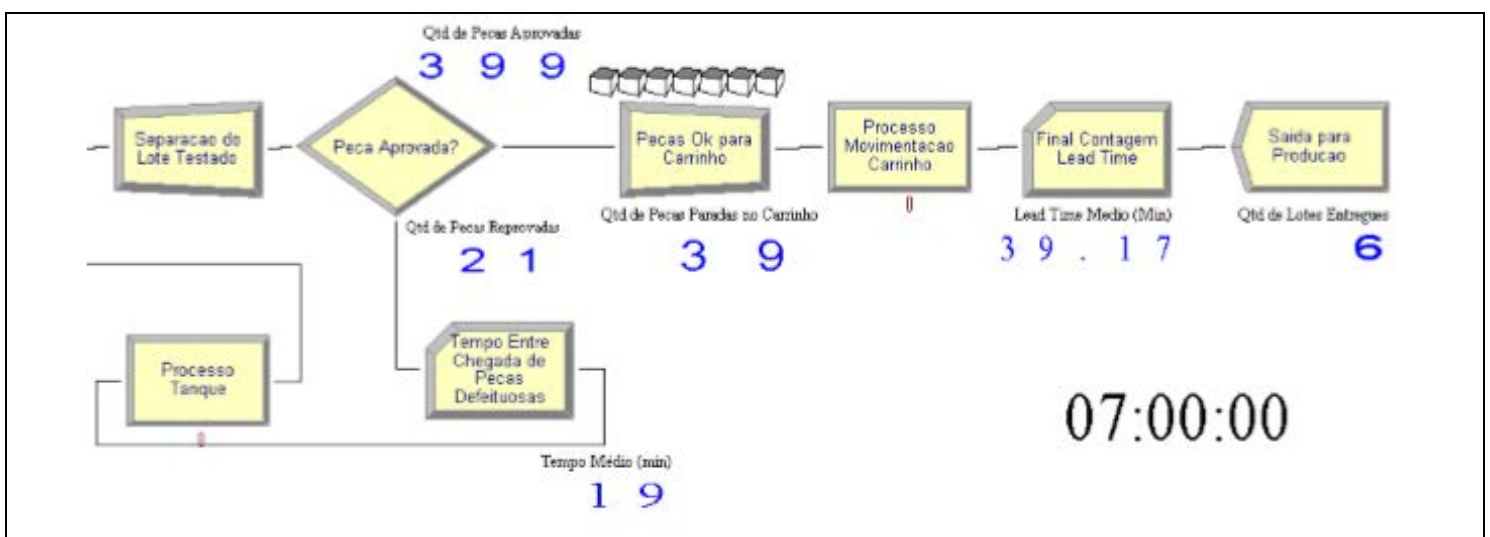

Figure 5: New proposed scenario (Part 2)

Source: Authors (2017)

Given this new scenario, we have the following configuration:

-Turn single working seven hours in six days.

- Relocation of welder for this shift.

- Acquisition of new Welding equipment.

With these settings, the new scenario that presented in its report the results shown in Figure 6 was simulated in ARENA: 


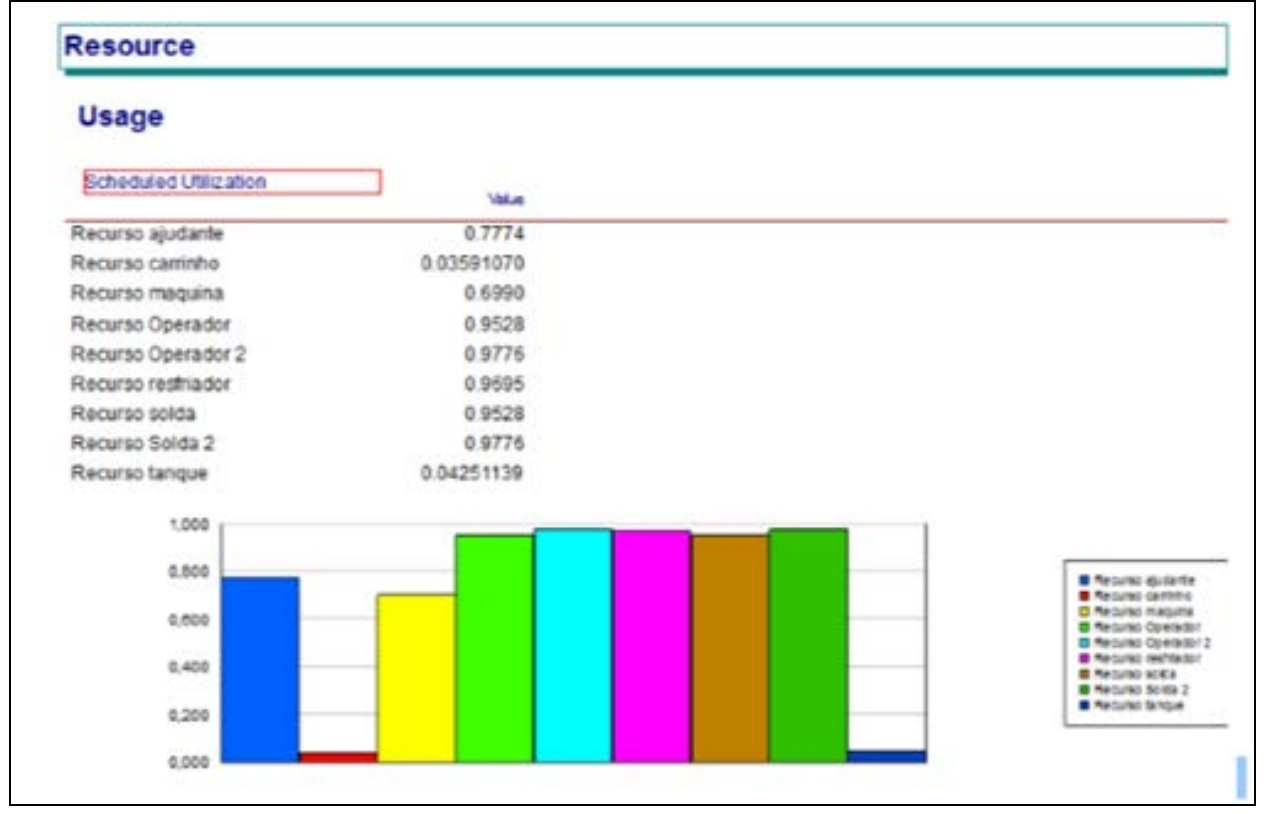

Figure 6: Report of the new scenario Source: The authors (2017)

From the data presented by the Arena simulator report it was possible to notice a considerable increase in the level of use of the Helper Resource, and thus having a balance of the line. This was only possible due to the relocation of the welder who demanded an increase in productivity in a single shift.

Comparing with the previous scenario, it is noticed that the percentage of use of the helper resource that was of $40,91 \%$ increased to $77,74 \%$, and the processes executed by him in the new scenario have a good level of occupation, because where before was $36.48 \%$, now rose to $69.90 \%$ for the test machine, and from 50 , $45 \%$ to $96.95 \%$ in the heat exchanger solder chiller, and from $27.43 \%$ to $42 \%, 51 \%$ in the tank that performs the leakage test on the exchangers that are rejected on the test machine.

A welder worked $100 \%$ of the shift to supply the demand of the production line, without causing inconveniences like the lack of finished parts. In the new scenario with two welders the level of occupation of one welder reduced to $95.28 \%$ and another welder reduced to $97.76 \%$, both working in a single shift.

For the company that currently works in two shifts, this new scenario presented will bring benefits, since it has the reduction of one shift, thus leaving this time available for possible events such as increased demand, machine breakdown, absence of employees, among other events. 
Another point to note is that in the current scenario we have 4 employees working in the cell, that is, 2 employees per shift. And with the new scenario we have only 3 employees acting in a single shift, and this represents a reduction of the cost with direct labor employed in the heat exchanger welding process.

\section{CONCLUSION}

The objective of this study was to identify and analyze the potential of operational research techniques, more specifically simulation, to perform the modeling of the problem and the application of the Arena simulator.

Currently, the production line of the company studied, operates in two shifts to supply the market demand and generate stocks for collective vacations and eventual setbacks.

The process of welding the heat exchanger, which is the main part of the gas water heater, takes place in two shifts and its welding production is matched to the production line to meet the right time.

It can be observed that from the analyses carried out, it is possible to suggest improvements in the flow of the analyzed operation. Although the simulation allows the times to be estimated and approximated to some typical probability distribution, the data used in this study are real and collected in the work cell. Several phases of the production process were identified and addressed in the proposed model.

The problem proposed by the study was how to reduce the idleness of a work cell, to balance the level of utilization of the resources and, thus, to increase the efficiency of the cell, and based on the results obtained through the simulation, it was verified that the implantation of the model will double the capacity of the current welding process, and the opportunity arises to reduce the welding process to a single turn, thus having sufficient service of welded parts to supply the demand of the two-shift heater production line currently.

The company will have the welding equipment available on a shift with the ability to weld parts to a possible surplus demand, for rework, for maintenance, or even generate a stock for possible process stops when needed. 


\section{REFERENCES}

ANDRADE, E. L. (2009). Introdução à pesquisa operacional: métodos e modelos para análise de decisões. $4^{\mathrm{a}}$ ed. LTC editora. Rio de Janeiro, p.124.

CALIXTO, F. (2011). Logística um enfoque prático. São Paulo: Saraiva, p. 76. CHWIF, L.; MEDINA, A. C, (2013). Modelagem e simuação de eventos discretos: teoria \& aplicações, $3^{\mathrm{a}}$ ed. Rio de Janeiro: Elsevier.

COX III, J. F.; SPENCER, M. S. (2002). Manual da Teoria das Restrições:

Prefácio de Eliyahu M. Goldratt. Porto Alegre: Bookman, p. 71.

FREITAS FILHO, P. J. (2008). Introdução à modelagem e simulação de sistemas: com aplicações em arena. $2^{\mathrm{a}}$ ed. Florianópolis: Visual Books.

MARTINS, P. G.; LAUGENI, F. P. (2005). Administração da Produção. $2^{\mathrm{a}} \mathrm{ed}$. rev. aum. e atual. São Paulo Saraiva, p. 31.

MOREIRA, D. A. (2004). Administração da produção e operações. São Paulo: Pioneira Thomson Learning, p. 295-296.

SLACK, N.; CHAMBERS, S.; JOHNSTON, R. (2002). Administração da Produção. $2^{\mathrm{a}}$ Ed. São Paulo: Atlas. 